The Irresistible Rise of Scottish Independence? A Brief History of Scotland's Constitutional Debate

\title{
Ben Jackson
}

\section{Published in Discover Society: New Series, 1 (2), 9 June 2021, online at https://discoversociety.org/2021/06/08/the-irresistible-rise-of-scottish-independence-a- brief-history-of-scotlands-constitutional-debate/}

While it is obvious that Scotland's political trajectory has significantly departed from England's, the explanation for this divergence is less straightforward. Social scientists have demonstrated that Scotland's economy, social structure, and even underlying values are not in fact that different from England's. To understand why Scottish electoral behaviour and public debate has followed a distinctive path, it is instead necessary to turn to the realms of politics and culture, where the same underlying socio-economic shifts that have transformed England's political landscape over the last fifty years have been filtered in a different direction in Scotland.

As the leading sociologist of modern Scotland, David McCrone, has put this point, a distinctive Scottish 'frame of reference' became more prominent in Scottish public life from around the 1970s onwards. The rise of this framing was produced by, among other things, the paradox that the mid-twentieth century rise of a centralised UK state committed to promoting economic welfare also highlighted Scotland's special status as a nation whose economy was managed quasi-autonomously by the Scottish Office, the arm of the state that had been established to govern Scotland in 1885. McCrone argues that the expansion of the Scottish mass media, notably the introduction of separate Scottish television news bulletins, popularised an understanding of Scotland both as a distinct economy and as a distinct polity gripped by its own particular political debates about how to address economic challenges. ${ }^{1}$

The rise of this Scottish framing was deepened in the 1980s as deindustrialisation accelerated. A clear Scottish political identity emerged that focused on national autonomy and presented this objective as expressing left-wing opposition to the dominant Conservative government in London. Until the 2014 referendum on Scottish independence, this leftist politics of national identity did not necessarily equate to support for the complete dissolution of the Anglo-Scottish Union. But, as I argue in my book, The Case for Scottish Independence, it is clear in retrospect that Scottish political discourse, as it developed across the 1980s and 1990s, had the effect of priming a large section of the Scottish electorate to support independence if faced with a choice between creating a new Scottish state and a Conservative government in London. ${ }^{2}$

As the results of the 2021 Scottish Parliament elections show, Scotland is now a divided nation, with roughly half of its citizens supporting full independence and the other half in 
favour of the constitutional status quo of devolution. How did the rise of McCrone's 'Scottish frame of reference' produce such a dramatic constitutional debate? ${ }^{3}$

The durability of the 1707 Anglo-Scottish Union derived in part from its legitimation within Scotland as a voluntary contract between sovereign states, a bargain that was said to have preserved for Scotland its distinctive national religious, legal and educational institutions in return for merging its parliament with that of England and Wales (and later Ireland).

Although Scottish culture did feature a consistent wistful romantic criticism of the Union as a bargain orchestrated by England using economic and diplomatic coercion, the hegemonic view of the Union as a beneficial contractual arrangement was not placed under serious pressure until the late twentieth century.

Economically, Scotland participated fully in the UK's development into the leading industrial and imperial power in the world in the nineteenth century. At a political level, Scotland was integrated into the British parliamentary system. While culturally Scotland remained a distinct nation, as Britain democratised during the nineteenth and early twentieth centuries each of the two major party systems that evolved (Conservative and Liberal; Conservative and Labour) bridged national distinctions between England, Scotland and Wales (the case of Ireland, of course, was very different). Within these integrative political and economic structures, space was also available for significant amounts of Scottish autonomy, notably (as we have seen) with the creation of the Scottish Office, which pioneered a form of administrative devolution long before its parliamentary counterpart.

More generally, Scottish identity in this period remained nested within a wider British imperial consciousness that transcended the islands of Britain and Ireland and thought of Britain not as a conventional nation-state but as an empire that linked the 'mother nations' of the UK to colonies around the world. As David Edgerton has argued, there is a sense in which Britain as a modern nation was a mid-twentieth century artefact, produced by the retreat from empire and global trade to the more autarchic, industrially-focused UK state of the 1940s, 1950s and 1960s. ${ }^{4}$

In these decades, a new form of British identity began to displace earlier connections forged around a shared Protestantism or imperialism as the main bulwark of the British unionstate, namely an image of the UK as a social democratic state committed to economic planning and social welfare. The Scottish National Party (SNP), founded in 1934, was only a fringe presence in popular politics at this time, but styled itself as a libertarian defender of Scottish national interests against the rise of the large impersonal bureaucracies that now drove British industrial development and redistributed economic resources. It was not at all successful, but the mere fact that dedicated activists were able to keep the party alive as an organisation across many decades of electoral unpopularity ensured that it would remain a possible outlet for voters when external circumstances became more favourable to a distinctively Scottish political appeal.

Circumstances did change in the 1970s, as an economic downturn and crisis-ridden Labour and Conservative governments drove voters to express their dissatisfaction via third party voting. The SNP had by this time positioned itself as a modernising force that backed a more 
decentralised model of government in order to address Scotland's economic challenges. Bolstered by the discovery of North Sea oil in Scottish waters, which significantly enhanced the economic credibility of an independent Scotland, the SNP soared to 30 per cent of the Scottish vote and 11 MPs in the October 1974 general election.

The rise in support for the SNP triggered a panicked attempt by Labour to introduce Scottish devolution, the first example of what has become a recurring pattern of the electoral threat posed by the SNP shifting the UK political elite (and in particular the Labour Party) towards supporting ever stronger forms of Scottish self-government. The attempt to introduce devolution failed in 1979, washed away in a referendum that stipulated that 40 per cent of the eligible electorate had to vote in favour for the measure to pass. This was a bar that campaigners for devolution could not clear in the face of internal divisions, an unpopular incumbent government, and a bleak economic landscape characterised by fractious industrial relations and high inflation (though of those who turned out to vote in the 1979 referendum a majority still voted in favour of devolution).

But the Thatcher and Major years forged a deeper political consensus within Scotland on the need for a Scottish Parliament. A crucial feature of this period was that voting in Scotland followed a markedly different pattern than in England, with Labour clearly winning in Scotland in 1979, 1983, 1987 and 1992. Since these were also the decades in which rapid deindustrialisation occurred - with accompanying increases in unemployment, poverty and income inequality - the startling social and economic changes of the 1980s and 1990s became understood in Scottish political culture as an undemocratic imposition from outside, visited on Scotland by an illegitimate government. The SNP did not significantly increase its support, but this was in part because the Scottish Labour Party adopted a quasi-nationalist rhetoric. Labour argued that the UK government lacked a democratic mandate to rule Scotland and presented itself as the guardian of Scottish national interests, which Labour maintained could best be advanced by a devolved parliament within the UK. Labour also pursued open dialogue with other parties and civil society organisations about the character of such a parliament through the Scottish Constitutional Convention (which the SNP chose to absent itself from because the Convention would not consider independence as a serious political option). Once Labour returned to office in 1997, devolution was duly delivered, ratified whole-heartedly in a successful referendum, and a new era in Scottish politics began with the first sitting of a democratically elected Scottish Parliament in 1999.

One important feature of the new devolved political system was that the SNP had clearly established itself as the second largest party (after Labour) in the 1999 Scottish Parliament elections. Although the SNP had supported the creation of the parliament, the party's leaders were committed to what had become known as the 'gradualist' strategy for Scottish independence. Devolution in their view represented an important staging post on the road to the creation of a new Scottish state, a project that they would seek to pursue if they ever entered government in Edinburgh.

The defenders of the devolutionary settlement, notably the Labour Party, did not take the presence of the SNP as a competitor for government office as seriously as they should have. Labour's years in control of the Holyrood parliament in coalition with the Liberal Democrats 
(1999-2007) were marked by a hubristic assumption that there was no need to continue, let alone deepen, their careful positioning in the 1980s and 1990s as the party best suited to advance the Scottish national interest. Indeed, it is striking in retrospect how dismissive of the prospect of Scottish independence the wider British political system was throughout this period. This was, after all, the New Labour era, in which a centre-left government had seemingly bound together Britain with a hegemonic electoral coalition that put them in office in London, Edinburgh and Cardiff. Tensions between the nations of the UK seemed to have been dissolved by the application of asymmetric devolution and a booming economy that in turn enabled a significant increase in the level of public spending.

This illusion was dispelled after 2007 on two fronts. Locally, it was in 2007 that the SNP capitalised on growing disenchantment with Labour in the wake of the Iraq War to emerge narrowly as the largest party at Holyrood and take office as a minority Scottish government. The SNP was elected on an appeal relating to governmental competence, with the question of independence parked as one that could only be resolved via a referendum at a later date. Globally, the financial crisis of 2007-8 transformed the terms of economic debate and eventually brought into power in London a Conservative-Liberal Democrat administration committed to a strikingly unequal distribution of the burdens of austerity. This new UK government elected in 2010 held 12 of the 59 Scottish seats at Westminster, only 1 of those won by the Conservatives.

The SNP was able to capitalise on Scottish opposition to this coalition to win a majority in the Scottish Parliament elections of 2011, significantly aided by the absence of any strategic purpose or strong leadership in the Scottish Labour Party. Independence was at this stage still an unpopular position in Scottish public opinion, favoured by perhaps only around a third of the electorate. Lulled into a false sense of security by this opinion polling, the UK government accepted that the 2011 victory granted the SNP a mandate to hold a referendum on whether to create a new Scottish state. Although supporters of the Union were indeed victorious in the 2014 referendum, the level of support for independence dramatically increased during the campaign, eventually finishing at 45 per cent of the vote on an exceptionally high turnout of 85 per cent of the electorate.

The framing of the referendum by the SNP as a choice between Scottish self-determination and the continuation of an unpopular Conservative government that lacked democratic legitimacy in Scotland was an artful one, which drew on the arguments about Scottish selfgovernment first developed in the 1980s and won over many Scots previously hesitant about independence. The referendum proved to be a moment of structural realignment in Scottish politics: pro-independence voters, many of whom had previously been Labour supporters, subsequently voted SNP, giving the party comfortable victories at the 2015 general election and then the 2016 Scottish Parliament election.

However, it was ultimately the referendum on Britain's membership of the EU in 2016 that brought the debate about Scottish independence back to the forefront of political debate. A key argument of supporters of the Anglo-Scottish Union in 2014 had been that an independent Scotland's prospects for membership of the EU were highly uncertain, so Scots might face exile from EU citizenship (even if only temporarily) if they voted to leave the UK. 
Of course, shortly afterwards the UK as a whole then voted to leave the EU, while Scotland registered a strong vote in favour of remaining (62 per cent voted for remain in Scotland as opposed to 48 per cent in the UK). The political significance of this vote was far wider than the specific issue of EU membership, since it provided another piece of evidence for supporters of independence that Scottish democratic preferences were doomed to be drowned out by a far larger English electorate.

In short, it provided a vivid illustration of the classic Scottish nationalist themes of the 1980s and 2010s, namely that the Anglo-Scottish Union was now a block on the democratic preferences of the Scottish people. The initial mobilisation of this argument by independence supporters was not as successful as they expected. Scots who voted for Brexit were still a large minority of the electorate, some of them SNP voters, and the 2017 UK general election in fact saw the SNP lose ground electorally. But support for the SNP was ultimately revitalised by the subsequent acrimonious debates over the details of Brexit, and then the high profile of the Scottish government during the pandemic, leaving the SNP unmatched as the dominant party in Scotland at the 2019 general election and the Scottish Parliament election in 2021.

Yet even then support for the SNP (or the SNP in combination with the pro-independence Greens) extends only to around one half of Scottish voters, with Labour, the Conservatives and the Liberal Democrats splitting the other half between them. While Scotland is therefore now a nation broadly divided between two equally sized blocs of voters, recent opinion polling also suggests that some fluidity between the two positions is possible. In 2020, for example, there was a clear movement towards majority support for independence in the opinion polling, in reaction to the UK government's initial maladroit response to the Covid pandemic, although this now seems to have unwound as vaccines are distributed and the economy reopens. But the very fact that public opinion can shift markedly in that direction indicates an underlying fragility to the Anglo-Scottish Union that was initially exposed in the 2014 referendum and has been exacerbated by subsequent events.

As long as Scottish nationalists can plausibly portray England as a conservative nation that thwarts the democratic will of the Scottish people, advocates of independence will have a resonant rhetorical frame at their disposal. They face from their opponents a barrage of detailed questions about the economics of independence and the transition to statehood, as well as a profound reluctance to entertain another referendum so soon after 2014 . It seems likely that the next few years will become dominated by this latter, procedural question at the expense of the more substantive former ones. The danger for the advocates of the Union is that such a posture will merely strengthen support for Scottish independence.

The Anglo-Scottish Union has for centuries been legitimated as a voluntary contract. For the UK government to depart from that well-rehearsed line of argument by denying a referendum risks playing into the hands of Scottish nationalists, who have always suspected that behind the seemingly consensual façade of the Union lurks the coercive force of an undemocratic, quasi-imperial state. Scotland's political future seems likely to hang in the 
balance unresolved for some time yet. But simply avoiding the argument altogether is a strategy that supporters of the Union will surely find has diminishing returns.

Ben Jackson is Associate Professor of Modern History at Oxford University and the co-editor of Political Quarterly. He is the author of The Case for Scottish Independence: A History of Nationalist Political Thought in Modern Scotland (Cambridge University Press, 2020) and coeditor of Making Thatcher's Britain (Cambridge University Press, 2012).

${ }^{1}$ David McCrone, 'Cultural Capital in an Understated Nation: The Case of Scotland', British Journal of Sociology, 56 (1), pp. 67-9, 76-9.

${ }^{2}$ Ben Jackson, The Case for Scottish Independence: A History of Nationalist Political Thought in Modern Scotland (Cambridge, Cambridge University Press, 2020).

${ }^{3}$ This article provides a concise outline of a complicated history. Readers interested in the full story will find the following excellent books helpful: Catriona MacDonald, Whaur Extremes Meet: Scotland's Twentieth Century (Edinburgh, John Donald, 2009); James Mitchell, The Scottish Question (Oxford, Oxford University Press, 2014); Tom Devine, Independence or Union? Scotland's Past and Scotland's Future (London, Penguin, 2016); David McCrone, The New Sociology of Scotland (London, Sage, 2017); Michael Keating, State and Nation in the United Kingdom: Fractured Union (Oxford, Oxford University Press, 2021). ${ }^{4}$ David Edgerton, The Rise and Fall of the British Nation: A Twentieth-Century History (London, Penguin, 2018). 